\title{
GAMBIR (Uncaria gambir Roxb) SEBAGAI PEWARNA ALAM KAIN BATIK SUTERA, KATUN, DAN RAYON
}

\section{Gambier (Uncaria gambir Roxb) as a Natural Dye of Silk, Cotton, and Rayon Batik Fabrics}

\section{Sofyan* dan Failisnur}

Balai Riset dan Standardisasi Industri Padang

Jl. Raya LIK No. 23 Ulu Gadut Padang

*e-mail: sofyantk84@gmail.com

Diterima: 19 Oktober 2016, revisi akhir: 8 Desember 2016 dan disetujui untuk diterbitkan: 10 Desember 2016

\section{ABSTRAK}

Gambir (Uncaria gambir Roxb.) merupakan salah satu komoditi unggulan Provinsi Sumatera Barat dimana hampir sebagian besar produknya diekspor dalam bentuk gambir mentah. Sangat banyak manfaat yang dapat diperoleh dari gambir, namun belum ada hilirisasi produk ini di dalam negeri. Tujuan penelitian adalah menggunakan gambir sebagai pewarna alam pada kain batik dan melihat kualitas kain batik yang telah diwarnai. Penelitian dilakukan dengan memvariasikan jenis kain (sutera, katun, dan rayon) dan jenis mordan atau pembangkit warna yaitu kapur $(\mathrm{CaO})$, tawas $\left(\mathrm{Al}_{2}\left(\mathrm{SO}_{4}\right)_{3}\right)$, dan tunjung $\left(\mathrm{FeSO}_{4}\right)$. Kain yang telah diwarnai dilakukan pengujian arah/beda warna, ketahanan luntur warna terhadap pencucian, sinar, gosokan, dan keringat asam dan basa. Hasil penelitian didapatkan warna ke arah kecokelatan dengan ketuaan warna yang berbeda-beda tergantung jenis mordan yang digunakan. Hasil pengujian ketahanan luntur warna rata-rata adalah baik sampai baik sekali. Bila ditinjau dari jenis kain, maka dari tiga jenis kain yang digunakan, kain sutera memberikan hasil terbaik dari segi ketahanan luntur warna terhadap pencucian, serta keringat asam dan basa dengan rata-rata hasil pengujian baik sampai baik sekali (skala 45). Penggunaan jenis mordan yang berbeda tidak memberikan pengaruh pada pengujian ketahanan luntur warna terhadap sinar dan gosokan.

\section{Kata kunci: Gambir, batik, sutera, katun, rayon}

\begin{abstract}
Gambier (Uncaria gambir Roxb.) is one of main commodities in West Sumatra Province where most of the products are exported in raw gambier form. Many benefits that can be derived from gambier, but there is no diversify of this product. The research was aimed to use gambier as natural dyes in batik fabric and to see the quality of the batik that had been dyed. The study was conducted by varying the type of fabric (silk, cotton, and rayon) and the type of mordant or color fixer namely lime $(\mathrm{CaO})$, alum $\left(\mathrm{Al}_{2}\left(\mathrm{SO}_{4}\right)_{3}\right)$, and ferous salt $\left(\mathrm{FeSO}_{4}\right)$. The fabrics which had been dyed were tested color direction, color fastness of washing, light, rubbing, moreover acid and alkaline perspiration. The results showed that the color direction was brownish with different color darkness depending on the type of mordant used. The results of testing on color fastness were good to excellent averagely. In term of the type of fabric, from the three types of fabric used, silk gave the best result in terms of color fastness of washing and perspiration of acid and alkaline with average test results was good to excellent (scale 4-5). The use of different types of mordant had not given significant effect on testing of color fastness to light and rubbing.
\end{abstract}

Keywords: Gambier, batik, silk, cotton, rayon 


\section{PENDAHULUAN}

Gambir merupakan bahan setengah jadi yang diperoleh dari ekstrak daun dan ranting tanaman gambir (Uncaria gambir Roxb.). Ekstraksi dilakukan secara panas melalui proses perebusan, pengempaan, pengendapan, penirisan, pencetakan, dan pengeringan (Sofyan et al., 2015). Produksi gambir di Sumatera Barat pada tahun 2014 tercatat 17.160 ton dengan luas lahan 32.307 hektar (BPS Provinsi Sumatera Barat, 2015).

Sebagian besar gambir di ekspor dalam bentuk gambir mentah (gambir asalan) sehingga hanya sedikit sekali memberi nilai tambah bagi petani dan pertumbuhan industri di Indonesia. Banyak industri yang dapat dikembangkan dari bahan gambir. Gambir asalan merupakan bahan setengah jadi yang dapat digunakan untuk berbagai keperluan industri, seperti industri makanan, industri farmasi, industri kosmetik, industri pigmen, dan industri lainnya (Kasim, 2011).

Saat ini harga gambir selalu ditentukan oleh pasar sehingga sangat merugikan petani dan pedagang gambir yang ada di daerah. Hilirisasi produk olahan gambir dan turunannya seperti pewarna alami pada produk tekstil merupakan salah satu pemecahan masalah sehingga petani dan pedagang gambir tidak bergantung pada pasar luar negeri, tetapi gambir dapat langsung dimanfaatkan di dalam negeri.

Industri tekstil merupakan salah satu industri yang diharapkan dapat membuat dan mengembangkan produk-produk dengan bahan pewarna alam yang bermutu dan tidak terus menerus menggunakan pewarna kimia. Semua pelaku IKM dan pengrajin yang berkecimpung dalam industri kreatif di Indonesia dihimbau untuk ikut menggunakan pewarna alam. Negaranegara maju seperti Jepang dan Korea melihat pengembangan warna alam merupakan pangsa pasar yang potensial di masa yang akan datang.

Sejak tahun 1996, beberapa negara Eropa mulai membatasi penggunaan pewarna kimia pada produk yang mempunyai kontak langsung dengan pemakainya. Bahkan di Jerman dan
Belanda, untuk produk clothing, footwear dan bedlinen tidak diperbolehkan menggunakan pewarna yang mengandung bahan kimia, yang mengacu pada CBI (Center for the promotion of imports from developing countries). Berdasarkan peraturan parlemen Eropa 2002/61/EC, Sejak September 2013 Uni Eropa telah melarang penggunaan beberapa zat warna azo yang biasanya digunakan sebagai pewarna sintetis untuk tekstil karena dampaknya terhadap lingkungan bersifat karsinogen (Puntener and Page, 2004).

Keunggulan penggunaan zat warna alam adalah karena memiliki nilai ekonomi dan nilai jual yang tinggi dan ramah lingkungan. Warna-warna tekstil yang menggunakan warna alam lebih khas dan lembut dibandingkan dengan warna sintetik sehingga mempunyai nilai estetika yang tinggi. Meskipun penggunaan zat warna alam mempunyai beberapa kelemahan dibandingkan dengan zat warna sintetis, namun masih terus digunakan hingga saat ini (Samanta and Agarwal, 2009).

Sebagai upaya mengangkat kembali penggunaan zat warna alam untuk tekstil maka diperlukan sumber zat warna dari potensi sumber daya alam lokal yang ada, ketersediaannya kontinyu dan berkesinambungan, produksi bahan baku stabil, dan bukan produk musiman, salah satunya adalah gambir.

Getah gambir mengandung beberapa senyawa kimia antara lain katekin (7-33\%), asam katechu tannat (20$55 \%$, pyrocatecol (20-30\%), gambir fluoresensi (1-3\%), katechu merah (3-5\%), quersetin $(2-4 \%)$, fixed oil (1-2\%), lilin (1$2 \%$ ) dan sedikit alkaloid (Thrope, IF Whiteley, MA, 1921 dalam Nazir, 2000).

Beberapa Penelitian pemanfaatan gambir untuk pewarna alami tekstil telah dilakukan oleh peneliti di Baristand Industri Padang. Dari hasil penelitian yang dilakukan oleh Yusmeiarti et al., (2007); Sofyan et al., (2012 dan 2013); Sofyan et al., (2014) penggunaan gambir sebagai pewarna tekstil telah dapat menghasilkan warna yang bervariasi tergantung konsentrasi zat warna dan zat pembangkit warna yang digunakan.

Failisnur dan Sofyan (2014) melakukan studi sifat tahan luntur dan 
intensitas warna kain polosan sutera dengan pewarna alam gambir (Uncaria gambir Roxb) pada kondisi pencelupan dan jenis fiksator yang berbeda. Hasil penelitian menunjukkan kondisi optimum diperoleh pada pencelupan panas (60$70^{\circ} \mathrm{C}$ ) dengan jenis fiksator $\mathrm{CaO}$ yang menghasilkan intensitas dan ketuaan warna lebih tinggi (nilai $\mathrm{K} / \mathrm{S}$ ) sebesar 19,174 dan ketahanan luntur warna terhadap pencucian $40^{\circ} \mathrm{C}$, sinar terang hari dan penekanan panas bernilai baik sampai sangat baik (4-5).

$$
\text { Failisnur dan Sofyan (2016) }
$$

melaporkan pengaruh suhu dan lama pencelupan benang katun pada pewarnaan alami dengan ekstrak gambir (Uncaria gambir Roxb). Hasil studi diperoleh bahwa intensitas warna tertinggi terdapat pada pencelupan $70^{\circ} \mathrm{C}$ dan waktu pencelupan 25 menit dengan menggunakan mordan $\mathrm{CaO}$. Failisnur et al., (2016) pada studi yang lain juga melaporkan pewarnaan benang katun mengggunakan metode mordan yang berbeda yaitu pra, pasca, simultan, dan kombinasi. Hasil optimum diperoleh pada metode mordan kombinasi.

Proses perlakuan akhir pada kain batik berbeda dengan kain polosan. Pada kain polosan hanya dilakukan proses pencucian saja, sedangkan pada kain batik diperlukan proses pelorodan untuk menghilangkan lilin yang digunakan pada pembatikan, kemudian baru dilakukan pencucian. Proses pelorodan menggunakan air dengan campuran soda abu dan kanji pada kondisi panas yang kemungkinan akan menyebabkan warna yang telah menempel akan luntur lebih banyak.

Atika et al., (2016) melakukan studi kualitas pewarnaan ekstrak gambir pada batik sutera dengan perlakuan jenis pelarut air dan etanol. Hasil penelitian diperoleh ketuaan warna paling tinggi adalah batik sutera dengan pelarut alkohol. Hasil ratarata ketahanan luntur warna terhadap pencucian, gosokan basah, dan sinar adalah baik.

Studi penggunaan tawas terhadap ketuaan dan ketahanan luntur warna pencelupan kain sutera dengan zat warna gambir dilakukan oleh Suheryanto dan Haryanto (2008). Hasil penelitian optimum diperoleh bahwa perlakuan yang memberikan ketuaan warna paling tinggi adalah penggunaan tawas $70 \mathrm{gram} / \mathrm{L}$.

Studi mengenai pengaruh perlakuan limbah dan jenis mordan kapur, tawas, dan tunjung terhadap mutu pewarnaan kain sutera dan katun menggunakan limbah cair gambir telah dilakukan oleh Sofyan et al., (2015). Bahan pewarna yang digunakan pada studi ini adalah limbah cair hasil proses pengempaan gambir dan bahan yang diwarnai adalah kain polosan yang tidak memerlukan proses pelorodan. Penelitian-penelitian yang dilakukan sebelumnya belum membahas mengenai kualitas kain yang dihasilkan pada penggunaan gambir sebagai pewarna batik untuk jenis kain yang berbeda.

Tujuan penelitian adalah mengggunakan gambir untuk pewarna alami kain batik sutera, katun, dan rayon dengan mordan kapur, tawas, dan tunjung serta melihat arah warna dan menguji kualitas kain batik yang telah diwarnai setelah melalui proses pelorodan.

\section{METODOLOGI PENELITIAN}

Bahan-bahan yang digunakan adalah gambir, kain sutera, kain katun, kain rayon, kapur $(\mathrm{CaO})$, tawas $\left(\mathrm{Al}_{2}\left(\mathrm{SO}_{4}\right)_{3}\right)$, tunjung $\left(\mathrm{FeSO}_{4}\right)$, soda abu, bahan-bahan untuk membatik dan bahan-bahan kimia untuk pengujian. Peralatan yang diperlukan adalah timbangan, pemanas, bak celup, termometer, saringan, alat-alat gelas, dan peralatan untuk pengujian diantaranya Spektrofotometer Colorscan SS 6200, Hunter Lab, Laundry meter, Crockmeter, Grey scale dan Staining scale.

Penelitian dilakukan dengan memvariasikan jenis mordan dan jenis kain yang diwarnai. Mordan yang digunakan yaitu tawas $\left(\mathrm{Al}_{2}\left(\mathrm{SO}_{4}\right)_{3}\right)$, kapur $(\mathrm{CaO})$, dan tunjung $\left(\mathrm{FeSO}_{4}\right)$, sedangkan jenis kain yang diwarnai yaitu katun, rayon, dan sutera. Gambir yang digunakan adalah gambir asalan yang diambil dari Siguntur Kabupaten Pesisir Selatan Provinsi Sumatera Barat.

\section{Prosedur Penelitian}

Sebelum dibatik dan diwarnai, kain dicuci dengan detergen ( $2 \mathrm{~g} / 10 \mathrm{~L}$ air), lalu 
dibilas sampai bersih dan dikeringkan. Kain yang sudah kering, siap diproses lebih lanjut untuk dimotif dengan lilin batik dan diwarnai.

Kain sutera/katun/rayon yang sudah dimotif dengan lilin batik lalu dicuci dan dikering anginkan. Dalam keadaan kering angin dicelupkan ke dalam larutan gambir $5 \%$ selama 10 menit. Kain yang sudah dicelup dikering anginkan kemudian pencelupan diulangi sampai tiga kali. Setelah proses pencelupan dengan pewarna gambir, dilakukan proses mordan dengan cara mencelupkan dalam larutan kapur $5 \%$ atau tawas $7 \%$, atau tunjung $3 \%$. Setelah dimordan kemudian dikeringkan, lalu dilakukan proses pelorodan.

Pelorodan bertujuan untuk melepaskan lilin batik pada kain yang telah diwarnai. Pelorodan menggunakan campuran soda abu dan kanji dengan cara melarutkan $250 \mathrm{~g}$ soda abu dan 500 kanji dalam $20 \mathrm{~L}$ air. Larutan pelorod dipanaskan sampai mendidih dan kain dimasukkan kedalam larutan pelorodan, sampai lilin larut seluruhnya. Kain yang telah dilorod, kemudian dicuci dengan air dingin sampai bersih dan dikeringkan.

\section{Pengujian kain hasil pewarnaan}

Pengujian kain yang sudah diwarnai, diuji terhadap:

1) Intensitas warna dengan menggunanakan Spektrofotometer Premier Colorscan SS 6200

2) Arah dan beda warna dengan metode skala warna CIE Lab 1975.

3) Ketahanan luntur warna terhadap pencucian $40^{\circ} \mathrm{C}$ meliputi: perubahan warna, penodaan warna terhadap asetat, kapas, poliamida, poliester, akrilat, dan wool (BSN, 2010: SNI ISO 105-C 06)

4) Ketahanan luntur warna terhadap sinar terang hari (BSN, 2010: SNI ISO 105B01)

5) Ketahanan luntur warna terhadap gosokan meliputi: nilai penodaan warna kapas kering dan kapas basah sesuai (BSN, 2008: SNI 0288-2008)

6) Ketahanan luntur warna terhadap keringat asam dan basa (BSN, 2010: SNI ISO 105-E04)
7) Kekuatan sobek (BSN, 2008: SNI 0521-2008)

\section{HASIL DAN PEMBAHASAN}

\section{Hasil Analisis Gambir dan Larutan Gambir 5\%}

Hasil analisis gambir asalan yang digunakan dan larutan gambir $5 \%$ ditampilkan pada Tabel 1. Kandungan utama dari gambir adalah tanin dan katekin. Kandungan tanin pada gambir asalan yang digunakan adalah $32,16 \%$, sedangkan pada larutan gambir $5 \%$ adalah $1,96 \%$. Tanin merupakan bahan yang berperan dalam proses pewarnaan tekstil. Kandungan tanin sangat menentukan mutu tekstil yang diwarnai dengan zat warna alam. Larutan gambir bersifat asam dengan hasil analisis $\mathrm{pH}$ larutan gambir $5 \%$ adalah 4,42 . Warna tekstil yang dihasilkan, selain ditentukan oleh reaksi garam dengan tanin, dipengaruhi juga oleh pH larutan pewarna (Kasim, 2011).

Tabel 1. Hasil analisis gambir dan Iarutan gambir $5 \%$.

\begin{tabular}{clcc}
\hline \multirow{2}{*}{ No. } & Parameter & \multicolumn{2}{c}{ Sampel } \\
\cline { 3 - 4 } & & Gambir & $\begin{array}{c}\text { Larutan } \\
\text { Gambir 5\% }\end{array}$ \\
\hline 1. & Tanin & $32,16 \%$ & $1,96 \%$ \\
\hline 2. & Katekin & $53,26 \%$ & - \\
\hline 3. & $\mathrm{pH}$ & - & 4,42 \\
\hline
\end{tabular}

\section{Hasil Pengamatan Arah Warna dan Ketuaan Warna}

Pewarnaan kain sutera, katun, dan rayon dengan mordan yang berbeda (kapur, tawas, dan tunjung) ditampilkan pada Tabel 2. Arah warna yang dihasilkan berbeda-beda. Hal ini disebabkan oleh reaksi tanin dan logam pada mordan yang digunakan pada proses fiksasi. Menurut Etherington (2002), tanin terkondensasi dalam larutan garam $\mathrm{Fe}^{3+}$ akan menghasilkan warna hijau kehitaman. Hal ini terlihat juga pada kain yang dimordan dengan tunjung yang merupakan garam $\mathrm{FeSO}_{4}$ menghasilkan nuansa warna ke arah hijau. Tanin merupakan senyawa polifenol yang akan memberikan warna 
hijau kehitaman dengan penambahan logam Fe (Setyowati et al., 2014). Reaksi tanin dengan ion $\mathrm{Fe}^{3+}$ akan membentuk senyawa kompleks seperti pada Gambar 1 (Harborne, 1987).

Bila dilihat secara visual, arah warna yang dihasilkan adalah kecoklatan sampai coklat kemerahan dengan ketuaan warna yang berbeda-beda. Kain rayon mempunyai ketuaan warna paling tinggi untuk mordan tunjung, kemudian diikuti dengan kain sutera dan kain katun yang mempunyai ketuaan warna paling rendah. Intensitas dan nilai beda warna dengan pengujian skala hunter Lab untuk masingmasing perlakuan ditampilkan pada Tabel
Nilai $L$ menunjukkan kecerahan warna dengan nilai 0 sampai 100 (hitam-putih). Nilai positif a adalah kemerahan dan negatif a adalah kehijauan, sedangkan nilai positif $b$ adalah kekuningan dan negatif $b$ adalah kebiruan. Nilai $L$ berkisar antara 23,92-64,89. Perlakuan yang menghasilkan ketuaan warna paling tinggi dengan nilai $L$ paling rendah adalah kain sutera yang dimordan dengan kapur. Perlakuan kain katun yang dimordan dengan tawas sebaliknya menghasilkan ketuaan warna paling rendah dengan nilai $L$ paling tinggi.

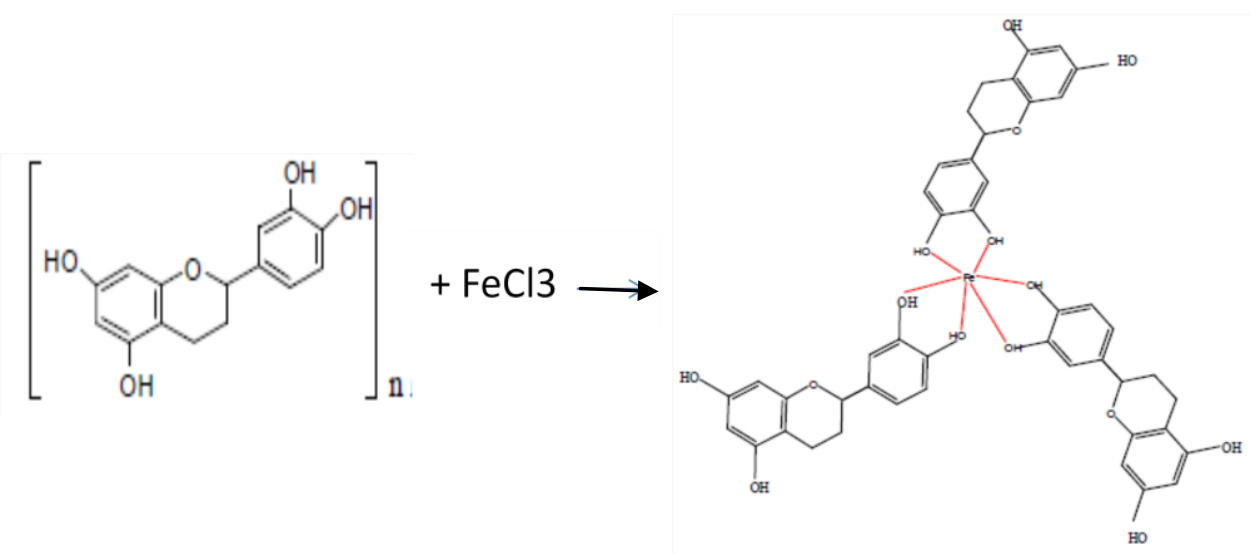

Gambar 1. Reaksi tanin dengan logam $\mathrm{Fe}^{3+}$ (Sumber: Harborne, 1987)

Tabel 2. Hasil pewarnaan kain batik dengan gambir pada berbagai perlakuan

Jenis Kain Jenis pengikat warna/mordan


Bila dilihat dari jenis serat kain dengan mordan tawas dan kapur, maka kain sutera memiliki nilai ketuaan warna paling tinggi dengan nilai $L \quad 23,92$ dibandingkan kain rayon dan kain katun. Pada penggunaan mordan tunjung, kain rayon memiliki ketuaan warna paling tinggi dengan nilai $L$ 25,74 dibandingkan kain sutera dan kain katun. Serat sutera dan rayon menyerap warna lebih baik dibandingkan serat katun. Hal ini disebabkan karena serat sutera adalah serat protein yang mempunyai daya serap lebih tinggi dari serat katun. Demikian juga halnya dengan serat rayon yang memiliki daya serap yang lebih tinggi dari serat katun karena luas permukaannya yang lebih besar.

Tabel 3. Intensitas dan nilai beda warna dari beberapa jenis kain batik

\begin{tabular}{ccccc}
\hline \multirow{2}{*}{$\begin{array}{c}\text { Jenis } \\
\text { Kain }\end{array}$} & Jenis & \multicolumn{3}{c}{ Arah Warna } \\
\cline { 3 - 5 } & Mordan & $\mathrm{L}^{*}$ & $\mathrm{a}^{*}$ & $\mathrm{~b}^{*}$ \\
\hline \multirow{3}{*}{ Sutera } & Tawas & 49,73 & 12,78 & 12,39 \\
& Kapur & 23,92 & 14,5 & 9,61 \\
& Tunjung & 38 & 9,03 & 6,42 \\
\hline \multirow{3}{*}{ Katun } & Tawas & 64,89 & 8,06 & 9,92 \\
& Kapur & 31,27 & 7,64 & 10,15 \\
& Tunjung & 42,05 & 4,06 & 5,97 \\
\hline \multirow{4}{*}{ Rayon } & Tawas & 55,8 & 8,39 & 11,02 \\
& Kapur & 26,26 & 13,9 & 11,39 \\
& Tunjung & 25,74 & 2,75 & 4,49 \\
\hline
\end{tabular}

Ditinjau dari penggunaan mordan, kain yang dimordan dengan kapur dan tunjung mempunyai ketuaan warna yang lebih tinggi dibandingkan dengan mordan tawas. Nilai L untuk mordan tawas, kapur, dan tunjung berturut-turut berkisar antara 49,73-64,89; 23,92-31,27; dan 25,74-42,05. Menurut Suheryanto (2010), fungsi dari larutan mordan pada pewarnaan tekstil yang menggunakan pewarna alam adalah untuk meningkatkan ketuaan atau intensitas warna dan memperkuat ikatan antar serat dan zat warna, sehingga dapat mencegah degradasi pigmen warna.

\section{Ketahanan Luntur Warna}

Hasil analisis ketahanan luntur warna kain batik terhadap pencucian $40^{\circ} \mathrm{C}$, keringat asam dan basa, sinar, dan gosokan dapat dilihat pada Tabel 4. Nilai perubahan warna adalah nilai yang diperoleh dengan membandingkan perbedaan warna dengan standar grey scale, sedangkan nilai penodaan warna pada kain putih pelapis adalah dengan membandingkan perbedaan warna dengan standar staining scale. Penilaiannya menggunakan skala nilai 5 (baik sekali, tidak ada perubahan warna kain atau penodaan warna terhadap bahan lain), nilai 4 (baik, sedikit terjadi perubahan atau penodaan warna), nilai 3 (cukup, terjadi perubahan atau penodaan warna), nilai 2 (sedang, terjadi perubahan atau penodaan warna yang menyolok) dan nilai 1 (kurang, terjadi perubahan dan penodaan warna yang sangat menyolok).

Bila ditinjau dari jenis kain yang digunakan, maka kain sutera memiliki ketahanan luntur warna terhadap pencucian lebih baik dibandingkan kain rayon dan katun. Hasil pengujian ketahanan luntur warna terhadap pencucian, sinar, gosokan, dan keringat kain batik sutera yang dimordan dengan tawas dan kapur adalah bernilai sama. Ketahanan luntur warna terhadap pencucian dan sinar untuk perlakuan ini adalah baik sampai baik sekali (4-5), sedangkan ketahanan luntur warna terhadap keringat asam dan basa adalah baik (4) untuk nilai perubahan warna.

Hasil ini tidak terlalu berbeda nyata dengan kain batik sutera yang dimordan dengan tunjung. Perbedaannya hanya pada ketahanan luntur warna terhadap pencucian yaitu bernilai baik (4). Hasil ini dapat dikatakan paling baik bila dibandingkan dengan kain batik rayon dan katun. Tidak ada pengaruh yang berbeda terhadap penggunaan jenis mordan yang berbeda pada pengujian ketahanan luntur warna terhadap sinar dan gosokan. 
Kain batik rayon juga memiliki ketahanan luntur warna yang baik sampai baik sekali untuk semua perlakuan jenis mordan seperti dapat dilihat pada Tabel 4 . Hasil ini masih lebih baik dibandingkan dengan kain batik katun. Kain batik katun bila dilihat secara keseluruhan memiliki ketahanan luntur warna yang baik sampai baik sekali, namun ada beberapa pengujian ketahanan luntur terhadap pencucian yang bernilai cukup sampai baik yaitu batik katun yang dimordan dengan tunjung. Batik katun yang dimordan dengan kapur memiliki nilai ketahanan luntur warna yang sama dengan batik sutera yaitu rata-rata baik sampai baik sekali.

Tabel 4. Hasil pengujian ketahanan luntur warna

\begin{tabular}{|c|c|c|c|c|c|c|c|c|c|}
\hline \multirow{2}{*}{ Jenis Uji } & \multicolumn{3}{|c|}{ Kain Batik Sutera } & \multicolumn{3}{|c|}{ Kain Batik Katun } & \multicolumn{3}{|c|}{ Kain Batik Rayon } \\
\hline & $\begin{array}{l}\text { Fixer } \\
\text { Tawas }\end{array}$ & $\begin{array}{l}\text { Fixer } \\
\text { Kapur }\end{array}$ & $\begin{array}{l}\text { Fixer } \\
\text { Tunjung }\end{array}$ & $\begin{array}{l}\text { Fixer } \\
\text { Tawas }\end{array}$ & $\begin{array}{l}\text { Fixer } \\
\text { Kapur }\end{array}$ & $\begin{array}{c}\text { Fixer } \\
\text { Tunjung }\end{array}$ & $\begin{array}{l}\text { Fixer } \\
\text { Tawas }\end{array}$ & $\begin{array}{l}\text { Fixer } \\
\text { Kapur }\end{array}$ & $\begin{array}{l}\text { Fixer } \\
\text { Tunjung }\end{array}$ \\
\hline $\begin{array}{l}\text { Pencucian } 40^{\circ} \mathrm{C} . \\
\text { - Perubahan warna } \\
\text { - Penodaan warna } \\
\text { (Asetat, Kapas } \\
\text { Poliamida,Poliester } \\
\text { Akrilat, Wool) }\end{array}$ & $\begin{array}{l}4-5 \\
4-5\end{array}$ & $\begin{array}{l}4-5 \\
4-5\end{array}$ & $\begin{array}{c}4 \\
4-5\end{array}$ & $\begin{array}{l}3-4 \\
4-5\end{array}$ & $\begin{array}{l}4-5 \\
4-5\end{array}$ & $4-5$ & $\begin{array}{c}4 \\
4-5\end{array}$ & $\begin{array}{c}4 \\
4-5\end{array}$ & $\begin{array}{l}4-5 \\
4-5\end{array}$ \\
\hline Sinar terang hari & $4-5$ & $4-5$ & $4-5$ & $4-5$ & $4-5$ & $4-5$ & $4-5$ & $4-5$ & $4-5$ \\
\hline $\begin{array}{l}\text { Gosokan } \\
\text { Penodaan warna } \\
\text { Kapas kering } \\
\text { Kapas basah }\end{array}$ & $\begin{array}{l}4-5 \\
4-5\end{array}$ & $\begin{array}{l}4-5 \\
4-5\end{array}$ & $\begin{array}{l}4-5 \\
4-5\end{array}$ & $\begin{array}{l}4-5 \\
4-5\end{array}$ & $\begin{array}{l}4-5 \\
4-5\end{array}$ & $\begin{array}{l}4-5 \\
4-5\end{array}$ & $\begin{array}{l}4-5 \\
4-5\end{array}$ & $\begin{array}{l}4-5 \\
4-5\end{array}$ & $\begin{array}{l}4-5 \\
4-5\end{array}$ \\
\hline $\begin{array}{l}\text { Keringat asam } \\
\text { - Perubahan warna } \\
\text { - Penodaan warna } \\
\text { (Asetat, Kapas } \\
\text { Poliamida,Poliester } \\
\text { Akrilat, Wool) }\end{array}$ & $\begin{array}{c}4 \\
4-5\end{array}$ & $\begin{array}{c}4 \\
4-5\end{array}$ & $\begin{array}{c}4 \\
4-5\end{array}$ & $\begin{array}{c}4 \\
4-5\end{array}$ & $\begin{array}{c}4 \\
4-5\end{array}$ & $\begin{array}{l}3-4 \\
4-5\end{array}$ & $\begin{array}{c}4 \\
4-5\end{array}$ & $\begin{array}{c}4 \\
4-5\end{array}$ & $\begin{array}{c}4 \\
4-5\end{array}$ \\
\hline $\begin{array}{l}\text { Keringat basa } \\
\text { - Perubahan warna } \\
\text { - Penodaan warna } \\
\text { (Asetat, Kapas } \\
\text { Poliamida,Poliester } \\
\text { Akrilat, Wool) }\end{array}$ & $\begin{array}{c}4 \\
4-5\end{array}$ & $\begin{array}{c}4 \\
4-5\end{array}$ & $\begin{array}{c}4 \\
4-5\end{array}$ & $\begin{array}{c}4 \\
4-5\end{array}$ & $\begin{array}{c}4 \\
4-5\end{array}$ & $\begin{array}{l}3-4 \\
4-5\end{array}$ & $4-5$ & $\begin{array}{c}4 \\
4-5\end{array}$ & $\begin{array}{c}4 \\
4-5\end{array}$ \\
\hline
\end{tabular}

Bila dibandingkan dengan studi yang dilakukan oleh beberapa peneliti mengenai zat warna alam untuk batik, penggunaan gambir sebagai pewarna batik menunjukkan ketahanan luntur warna yang sama, bahkan ada juga yang lebih baik. Pujilestari (2014) melakukan studi ketahanan luntur warna terhadap beberapa zat warna alam yaitu daun indigo, daun mangga, kulit kayu nangka, kulit buah manggis, dan biji buah kesumba pada kain batik katun. Hasil penelitian menunjukkan bahwa perlakuan yang memberikan ketahanan luntur baik adalah: kulit buah manggis dengan fiksasi kapur, tawas dan tanpa fiksasi, biji buah kesumba/bixa dengan fiksasi tunjung dan tawas, kulit kayu nangka dengan fiksasi tunjung, daun mangga dengan fiksasi tawas. Daun indigo mempunyai ketahanan luntur warna yang baik sampai sangat baik terhadap pencucian, tetapi kurang baik sampai baik terhadap sinar terang hari. Penggunaan fiksasi campuran kapur dan tetes tebu menghasilkan ketahanan luntur warna pencucian dan sinar terang hari lebih rendah dibanding fiksasi dengan kapur.

Prayitno, et al. (2014) melakukan studi ketahanan luntur warna kain mori batik dengan menggunakan pewarna alami serbuk daun alpukat dan melaporkan bahwa uji ketahanan gosokan kering dan basah menunjukkan nilai SS (Stainning Scale) sebesar 2.00 (baik) dan 5.87 (cukup 
baik). Uji ketahanan pencucian menunjukkan nilai SS (Stainning Scale) sebesar 3.87 (baik) dan nilai GS (Grey Scale) sebesar 0.67 (baik sekali).

Bila ditinjau terhadap kualitas batik yang ada di pasaran saat ini, ketahanan luntur warna batik dengan gambir tidak kalah baiknya. Studi yang dilakukan oleh Atikasari (2005) terhadap kualitas tahan luntur warna batik cap di griya batik larissa pekalongan diperoleh bahwa hasil analisis deskriptif menunjukkan bahwa kualitas tahan luntur warnabatik cap terhadap pencucian, gosokan, keringat dan panas penyetrikaan di griya batik Larissa mempunyai nilai baik. Kasmudjo dan Saktianggi, (2011) melaporkan pemanfaatan daun indigofera sebagai pewarna alam batik dan mendapatkan nilai pengujian ketahanan luntur warna dan penodaan terhadap keringat asam dan pencucian $40^{\circ} \mathrm{C}$ serta ketahanan luntur warna terhadap sinar matahari yaitu hasil 4-5. Hasil ini hampir sama dengan ketahanan luntur warna yang dilakukan dengan pewarna gambir dimana hasil ketahanan luntur warna yang diperoleh rata-rata baik sampai baik sekali (4-5).

\section{Kekuatan Sobek}

Pengujian kekuatan sobek dimaksudkan untuk melihat pengaruh zat warna gambir yang digunakan terhadap ketahanan sobek kain yang diwarnai. Data kekuatan sobek batik katun ditampilkan pada Tabel 5.

Dari hasil pengujian dapat dilihat bahwa rata-rata kekuatan sobek kain yang dibatik dan dicelup dengan gambir lebih besar dari kekuatan sobek kain blanko. Hal ini menunjukkan bahwa perlakuan pencelupan dengan gambir dan mordan tidak menurunkan kekuatan sobek kain. Perbedaan ketahanan sobek yang dihasilkan kemungkinan disebabkan karena perbedaan kekuatan sobek pada masing-masing bagian dari masing-masing kain.

Tabel 5. Hasil pengujian kekuatan sobek kain batik

\begin{tabular}{cccc}
\hline \multicolumn{2}{c}{ Kode Contoh } & \multicolumn{2}{c}{ Kekuatan sobek } \\
\hline Jenis kain & Jenis mordan & Lusi & Pakan \\
\hline \multirow{3}{*}{ Katun } & Blanko & 4,66 & 4,66 \\
& Tawas & 4,91 & 5,49 \\
& Kapur & 6,87 & 7,06 \\
& Tunjung & 4,91 & 6,62 \\
\hline \multirow{5}{*}{ Sutera } & Blanko & 6,13 & 6,62 \\
& Tawas & 7,36 & 13,73 \\
& Kapur & 4,41 & 10,06 \\
& Tunjung & 11,04 & 6,38 \\
\hline \multirow{3}{*}{ Rayon } & Blanko & 20,36 & 22,32 \\
& Tawas & 29,43 & 31,64 \\
& Kapur & 32,86 & 30,90 \\
& Tunjung & 27,22 & 21,58
\end{tabular}

\section{KESIMPULAN}

Pemanfaatan gambir sebagai pewarna alam pada batik merupakan prospek yang cukup baik untuk dikembangkan dan warna yang dihasilkan ke arah kecokelatan dengan ketuaan warna yang berbeda-beda tergantung jenis mordan yang digunakan. Kain yang dimordan dengan kapur dan tunjung mempunyai ketuaan warna yang lebih tinggi dibandingkan dengan mordan tawas. Nilai L untuk mordan tawas, kapur, dan tunjung berturut-turut berkisar antara 
49,73-64,89; 23,92-31,27; dan 25,7442,05. Hasil pengujian ketahanan luntur warna rata-rata adalah baik sampai baik sekali (skala 4-5). Bila ditinjau dari jenis kain, maka dari tiga jenis kain yang digunakan, kain sutera memberikan hasil terbaik dari segi ketahanan luntur warna, kemudian kain rayon dan terakhir kain katun. Bila ditinjau dari jenis mordan, maka ketiga jenis kain memperlihatkan hasil yang berbeda. Mordan tawas dan kapur memperlihatkan hasil terbaik dengan kualitas yang sama untuk kain sutera, mordan kapur memperlihatkan hasil terbaik untuk kain katun, dan mordan tunjung memperlihatkan hasil terbaik untuk kain rayon.

\section{UCAPAN TERIMA KASIH}

Kami sampaikan terima kasih kepada Marlusi dan Sulastri atas kerjasamanya yang telah membantu pelaksanaan penelitian.

\section{DAFTAR PUSTAKA}

Atika, V., Farida, dan Pujilestari, T. 2016. Kualitas pewarnaan ekstrak gambir pada batik sutera. Dinamika Kerajinan dan Batik. 33 (1): 25-32.

Atikasari, A. 2005. Kualitas tahan luntur warna batik cap di Griya Batik Larissa Pekalongan. Universitas Negeri Semarang Press. Semarang.

BPS Provinsi Sumatera Barat. 2015. Sumatera Barat dalam angka. Badan Pusat Statistik Sumatera Barat.

BSN. 2008. SNI 0288: 2008. Uji ketahanan luntur warna terhadap gosokan (nilai penodaan warna). Badan Standardisasi Nasional. Jakarta.

BSN. 2008. SNI 0521: 2008. Uji kekuatan sobek. Badan Standardisasi Nasional. Jakarta.

BSN. 2010. SNI ISO 105-C 06: 2010. Uji ketahanan luntur warna terhadap pencucian $40^{\circ} \mathrm{C}$ (perubahan dan penodaan warna). Badan Standardisasi Nasional. Jakarta.
BSN. 2010. SNI ISO 105-B01: 2010; Uji ketahanan luntur warna terhadap sinar terang hari. Badan Standardisasi Nasional. Jakarta.

BSN. 2010. SNI ISO 105-E04: 2010; Uji ketahanan luntur warna terhadap keringat asam dan basa. Badan Standardisasi Nasional. Jakarta.

Etherington, R. 2002. A Dictionary Of Descriptive Terminology: Vegetable Tannin.http://palimpsest. standart.edu./don/dt.3686.html. Diakses tanggal 4 Januari 2014.

Failisnur dan Sofyan. 2014. Sifat tahan luntur warna dan intensitas warna kain sutera dengan pewarna alam gambir (Uncaria gambir Roxb) pada kondisi pencelupan dan jenis fiksator yang berbeda. Jurnal Litbang Industri, 4 (1): 1-8.

Failisnur dan Sofyan. 2016. Pengaruh suhu dan lama pencelupan benang katun pada pewarnaan alami dengan ekstrak gambir (Uncaria gambir Roxb). Jurnal Litbang Industri, 6 (1): 25-37.

Failisnur, Sofyan, Kasim., A. 2016. Dyeing of cotton fabric with natural dye from gambier (Uncaria gambir Roxb.). 3rd. Natural pigments conference for South East Asia: 47-49.

Harborne, J. B. 1987. Metode fitokimia penuntun cara modern menganalisis tumbuhan, diterjemahkan oleh Padmawinata, K. ITB, Bandung.

Kasim, A. 2011. Proses produksi dan industri hilir gambir. Andalas University Press, Padang.

Kasmudjo dan Saktianggi, P. P. 2011. Pemanfaatan daun indigofera sebagai pewarna alami batik. bagian teknologi hasil hutan, Fakultas Kehutanan, Universitas Gadjah Mada, Yogyakarta. Prosiding Seminar Nasional Masyarakat Peneliti Kayu Indonesia (MAPEKI) XIV: 542-548.

Nazir, N. 2000. Gambir, budidaya, pengolahan dan prospek diversifikasinya. Yayasan Hutanku. Padang. 
Prayitno, R. E., Wijana, S., dan Diyah, D. B. S. 2014. Pengaruh bahan fiksasi terhadap ketahanan luntur dan intensitas warna kain mori batik hasil pewarnaan daun alpukat (Persea americana Mill.). Jurusan Teknologi Industri Pertanian - Fakultas Teknologi Pertanian, Universitas Brawijaya. Malang.

Pujilestari, T. 2014. Pengaruh ekstraksi zat warna alam dan fiksasi terhadap ketahanan luntur warna pada kain batik katun. Dinamika Kerajinan dan Batik, 31(1): 1-9.

Puntener, A and Page, C. 2004. European ban on certain Azo dyes, quality and environment. www.tfl.com.

Samanta, A. K. \& Agarwal, P. 2009. Application of natural dyes on textiles. Indian Journal of Fibre \& Textile Research, Vol. 34: 384-399.

Setyowati, W. A. E., Ariani, S. R. D., Ashadi, Mulyani, B., Rahmawati, C. P. 2014. Skrining fitokimia dan identifikasi komponen utama ekstrak metanol kulit durian (Durio zibethinus Murr.) varietas petruk. Prosiding seminar nasional kimia dan pendidikan kimia VI. FMIPA, FKIP, UNS, Surakarta.

Sofyan, Failisnur, Salmariza Sy. 2015. Pengaruh perlakuan limbah dan jenis mordan kapur, tawas, dan tunjung terhadap mutu pewarnaan kain sutera dan katun menggunakan limbah cair gambir (Uncaria gambir Roxb). Jurnal Litbang Industri, 5 (2): 79-89.
Sofyan, Failisnur, Salmariza Sy. 2012. Laporan penelitian peningkatan teknologi proses pencelupan kain sutera dengan memanfaatkan limbah cair gambir. Baristand Industri Padang.

Sofyan dan Failisnur. 2013. Laporan penelitian pengembangan gambir sebagai pewarna alami produk tekstil. Baristand Industri Padang.

Sofyan dan Failisnur. 2014. Laporan penelitian pengembangan pewarna alam gambir pada proses pembatikan. Baristand Industri Padang.

Suheryanto, D., \& Haryanto, T. 2008. Pengaruh konsentrasi tawas terhadap ketuaan dan ketahanan luntur warna pada pencelupan ain sutera dengan zat warna gambir. Dinamika Kerajinan dan Batik, 25: 9-16.

Suheryanto, D. 2010. Optimalisasi celupan ekstrak daun mangga pada kain batik katun dengan iring kapur. Prosiding Seminar Nasional Rekayasa Kimia dan Proses. Jurusan Teknik Kimia Fakultas Teknik Universitas Diponegoro Semarang.

Yusmeiarti, Failisnur, Hermianti, W., Marjali, Syafruddin, D., dan Yurnita. 2007. Laporan penelitian stabilisasi dalam penyimpanan limbah pengolahan gambir sebagai pewarna tekstil. Baristand Industri Padang. 